DOI : $10.14746 /$ rie.2015.9.14

Uniwersytet im. Adama Mickiewicza w Poznaniu

\title{
Military-Industrial aspects of Turkish defence policy
}

Republic of Turkey is one of the leading regional powers in the Middle East North Africa (MENA) region. It is also considered to be one of the most promising "emerging powers" on the global level in both its economic potential and political clout (The Mint countries..., 2014). In the course of the last decade Turkey has pursued an activist foreign policy in its extended neighbourhood, positioning itself as an important player in the most important issues of international relations in the MENA region. This trend has been most recently and starkly illustrated by the ongoing crisis revolving around the advance of the so called Islamic State (IS). Turkey's position and policy are widely considered to be crucial for the effectiveness of international coalition's efforts at diminishing this threat. All this developments make Turkish defence and security policy an important factor shaping international security in the MENA (Barkey, 2014).

This paper aims to analyse the military-industrial aspects of Turkish defence policy. Sophisticated and profitable defence industry is a useful tool for state's foreign and security policy. It not only supplies armed forces with required weapons and military equipment but can also bring political influence on the international arena through arms transfers and military-industrial cooperation. These realities are not lost on Turkish decision makers. That is why they have made the nurturing of indigenous defence-industrial base a distinct state policy. In the course of this paper defence industry's functions in the frame of Turkish defence and security policy will be defined, the condition and structure of that state's defence \& aerospace sector will be analysed and conclusions regarding its future prospects will be presented. This will provide basis for a wider analysis of defence-industrial aspects of Turkish defence and security policy.

\section{Roles of defence industry in Turkish defence and security policy}

In every state, the defence industry basically plays three broad and mutually supportive roles: military, political and economic.

The military role is the original raison d'etre for the entire defence-industrial base and arguably still is the main driving force behind state support for this sector. On the most basic level it amounts to equipping the national armed forces with weapon systems and military equipment enabling them to achieve tactical, operational and strategic military objectives assigned to them in both peace and war time. This complicated process is comprised of several distinct phases, including research \& development of new technologies, development of final products, production, servicing and decommissioning of platforms and systems. Companies comprising the defence industry have a role to play in every step of this process. Traditionally focused on R\&D and produc- 
tion they are increasingly engaged in training, maintenance, repairs, refurbishment and modernisation of military equipment. Thus their role in the maintenance of national military capabilities is steadily growing.

In the Turkish context, the military role of the defence industry is shaped by three specific factors. First, it has to support an extensive defence posture. Turkish armed forces number 510,600 active duty personnel, which makes them 9th biggest in the world and 2nd biggest in NATO (The Military Balance, 2014, p. 486-492). They maintain a force of 2504 Main Battle Tanks, 352 combat capable aircraft, 19 principal surface combatants and 14 submarines (The Military Balance, 2014, p. 146-148). Such a large structure generates a considerable demand for defence products in almost all categories, including the most sophisticated combat systems. Second, for more than a half century Turkey has been engaged in an arms race with Greece. It has been only one aspect of both states' intense rivalry motivated chiefly by the Cyprus issue and territorial disputes in the Aegean Sea (Defence and Security Policy, 2011, p. 245-246). Although in the last two decades relations between Turkey and Greece improved significantly, it can be claimed that their defence procurement programs are still correlated to a large degree and show patterns of interdependence (Dunne, Nikolaidou, Smith, 2005). Third, current Turkish military doctrine of forward defence and growing aspirations to a regional power status place additional premium on power projection capabilities. Since the 1990s Turkey adopted the forward defence doctrine which envisioned confronting threats to national security before they reach national borders (Karaosmanoglu, Kibaroglu, 2003, p. 5-8). From the operational standpoint that puts the premium on swift joint operations conducted outside the national territory. Moreover, growing regional and global presence of Turkish citizens and companies, as well as expanding diplomatic activity, generate demands for long-distance power projection. This trend can be exemplified by evacuation of Turkish nationals from Libya in 2011 (Turkey demonstrates..., 2011) or unrealised plans for naval escorts to accompany further aid flotillas sailing to Gaza (Erdogan, 2011). In this context it is also important to mention a demanding regional security environment in which Turkish security policy must be conducted. MENA is one of the most violent and turbulent regions of the world. Even the most immediate neighbourhood of Turkey is rife with serious armed conflict engulfing Iraq and Syria. Coupled with unresolved crisis surrounding Iran's nuclear ambitions and its wider regional policy, it creates a threat-rich security environment which necessitates the maintenance of a robust and effective military posture. Considering all aforementioned factors, it seems obvious that the demand for Turkish defence industry's military functions is strong and will remain so in the foreseeable future.

Defence industry's political role concerns primarily state's standing in international politics. Arms exports are not only profitable commercial undertaking but can also be used to exercise political influence. Not many states in the world are able to develop and manufacture the most sophisticated weapon systems. Those who can, attain a level of independence in pursuance of their foreign and defence policy, as they can equip and operate their armed forces on their own, without constrains imposed by a foreign supplier. At the same time exports of such products can complement politico-military alliances and "buy" political influence in importing states. Prestige should also not be excluded as a motive for state action. Domestic industry's ability to develop 
and produce advanced, high-technology weapon systems (such as, for example: combat aircraft, air defence systems, large surface warships and submarines) is a widely-recognised symbol of technological and industrial prowess and can be turned into an attribute of great power status.

Robust defence-industrial base carries important value in the context of foreign policy currently pursued by Turkey. During a decade of rule by the Justice and Development Party (AKP) Ankara has aspired to growing independence and even assertiveness in its foreign relations. Traditionally close ties to the West (and especially United States) have not been severed. However, Turkish government expressed propensity for breaking with their allies' stance when it believed that to be suitable for national interests. This shift has been widely interpreted through such concepts as "strategic depth" and "zero problems with neighbours" authored and promoted by Ahmet Davutoglu (first foreign minister and now prime minister in AKP cabinets). Notwithstanding controversies surrounding this concepts' validity and the true extent of their implementation, it is true that Turkish foreign policy has lessened its alignment with the general stance of NATO/EU and USA and more vigorously charted its own course (Strategic Survey, 2013, p. 143-151; Ozkan, 2014). This trend was clearly visible in the run-up to the Iraq War in 2003, when Turkey refused to allow its territory to be used as a base for the attack. During following years Ankara has all but terminated its informal alliance with Israel, surprised the West through a joint diplomatic initiative with Brazil to solve the Iranian nuclear crisis and only reluctantly joined the efforts of US-led coalition aimed at defeating the so-called Islamic State. Implications of this shift for military-industrial policy are quite profound. Traditionally Turkish armed forces have relied on American and West European suppliers for its armaments and military equipment. Turkish defence industry has closely collaborated with US and other NATO partners on important programmes through licence production and technology transfer (a good example is the rise of Turkish Aerospace Industries thanks to final assembly of F-16 fighters, see later on in the paper). However, as already explained, such an arrangement created opportunities for Western governments to influence Turkish foreign and security policy by for example withholding the transfer of important technologies or components. It is worth to mention at this point that US government has acquired a notorious reputation for exercising control over exported military kit for both political and commercial ends (Sislin, 1994). Considering these circumstances, it is hardly surprising that government of Turkey adopted the view that development of national defence-industrial base can help build foundations for more independent foreign policy.

Sophisticated defence-industrial base can contribute to attainment of regional power status in several ways. First, as already explained, it is done through supplying state's armed forces. Secondly, through exports, which can form a part of a wider politico-military cooperation between states. As Turkey has expanded its commercial interactions throughout the MENA region, and further away in Africa, Caucasus, Central and South Asia, defence sector has also followed this geographical trajectory. It is worth pointing out that main importers of Turkish defence products in a decade to 2013 have been: Pakistan, Malaysia, Iraq and Georgia (SIPRI). Naturally, the success of Turkish companies in those states is an cumulative effect of many factors (both commercial and political) but the geographical distribution of important contracts does cor- 
respond to main geopolitical vectors of interest of Turkish foreign policy. In this context the example of Azerbaijan is illustrative. Due to its unresolved conflict with Armenia, Baku is investing heavily in its military and develops its own defence-industrial base. Turkish defence companies are very active in this market and have been able to score several important successes (Gyürösi, 2014). This activity needs to be viewed in the wider context of close political ties between Turkey and Azerbaijan. Finally, the benefits of prestige stemming from successful development of advanced weapon systems must not be overlooked in Turkish context. Such expressions of technological and industrial prowess are valuable for an emerging power aspiring to join the ranks of major developed economies. This explains the presence of highest-ranking government figures during official presentations of new military hardware.

Defence industry must be viewed not only as a support base for the armed forces and a complement to foreign policy, but also as an important sector of the national economy. The scale of revenues and employment it provides are sources of defence industry's economic role. Companies operating in this sector typically generate significant profits, invest heavily in (among other things) development of advanced technologies and employ large numbers of skilled workers. Through all these channels they contribute to economic growth, industrial and technological development, as well as social welfare. Such benefits cannot be overlooked in any circumstances, and especially at the time of global economy's problematic condition, as currently experienced. It can even be argued that currently, for states which do not face an imminent military threat, economic role of the defence industry is as important, or perhaps even more important than the military one. Many weapon development programmes have been judged to be aimed more at sustaining the industrial base and employment in it than at military capabilities' generation.

To asses defence sector's significance for the Turkish economy some data on its scale and performance need to be presented. Each year Turkish Defense and Aerospace Industry Manufacturers Association compiles data on the performance of the sector (it includes also civil aerospace industry). According to those statistics in year 2013 the turnover of Turkish aerospace and defence sector amounted to $5.076 \mathrm{bn} \$$ (that is the fourth consecutive year of healthy growth, the turnover grew cumulatively by $66 \%$ since 2009). Not surprisingly the highest turnover per employee has been recorder in the defence aerospace subsector $(168,715 \$$ ). The value of exports reached $1.569 \mathrm{bl} \$$ (it amounts to an $84 \%$ increase compared to year 2010). At the same time R\&D-R\&T expenditure amounted to $926 \mathrm{mS}$ (increase of ca. 39\% compared to 2010 level) which was an equivalent of $18 \%$ of the generated turnover. Turkish aerospace and defence sector employed 32,368 people in 2013. The Weapons-Ammo Rocket \& Missiles subsector had the biggest share of this workforce (ca. $25 \%$ of the total), followed closely by the Air-Space platforms subsector with ca. 24.8\% of the total (Defence Turkey, 2014, p. 12-18). These data paint a picture of Turkish defence and aerospace industry as a sizable and dynamic sector of the economy with substantial growth potential. It is also worth to remember that defence industry in general is a high-tech sector, whose activity is conductive to the goal of building an "knowledge-based economy." Defence and aerospace sector's substantial $R \& D$ expenditure are important in the context of Turkey's evolution from a middle-income to a developed economy. 


\section{Turkey as an actor on the international arms market}

In order to characterize Turkey's position as an actor on the international arms market three factors need to be considered: value of both arms imports and exports, their respective structures and position of key Turkish defence companies in the global industry.

Analysis of value and structure of Turkish defence imports and exports is based on data from SIPRI arms transfers database (SIPRI). Firstly, it must be noted that these data do not correspond with export figures published by the Turkish Defense and Aerospace Industry Manufacturers Association. Methodological differences account for these discrepancies. ${ }^{1}$ SIPRI dataset has been chosen for the this paper in order to illustrate long term structural features in Turkish international arms trade (for the decade between 2003-2013). In the period under consideration Turkey has imported $7.485 \mathrm{bl} \mathrm{S}$ worth (by TIV value) of arms and military equipment. Four biggest suppliers (accounting for $85 \%$ of deliveries) were United States (ca. 30\% of the total), Germany (ca. $27 \%$ ), Republic of Korea (ca. 18\%) and Israel (ca. 9\%). Data on imports' composition by weapon category show that ships and aircraft accounted for $41 \%$ of imports by value, while artillery and armoured vehicles comprised another $35 \%$. In the decade under consideration Turkey has exported defence products worth $560 \mathrm{~m} \$$ (by TIV value). Four biggest recipients accounted for ca. 59\% of the total. Those states were: Pakistan (ca. $27 \%$ of total exports value), Malaysia (ca. 16\%), Iraq (ca. 12\%) and Georgia (10\%). When it comes to exports' division by weapon category, armoured vehicles and artillery accounted for ca. $77 \%$ of the total, with ships comprising another $22 \%$.

Data compiled by the Turkish Defense and Aerospace Industry Manufacturers Association present an interesting picture concerning the shift in geographical patterns of Turkish defence exports (it should once again be noted that these data are compiled using different methodology then SIPRI's TIV tables leading to large discrepancies in value of exports between these two data sets). According to this source, in year 2011 Turkey exported defence products worth 1.089 blS. Their distribution between Europe and Outside Europe recipients was 64\%:36\%. However, only two years later $1.569 \mathrm{blS}$

As explained by its authors: "[...] SIPRI has developed a unique system to measure the volume of international transfers of major conventional weapons using a common unit, the trend-indicator value (TIV). The TIV is based on the known unit production costs of a core set of weapons and is intended to represent the transfer of military resources rather than the financial value of the transfer. [...] SIPRI calculates the volume of transfers to, from and between all parties using the TIV and the number of weapon systems or subsystems delivered in a given year. This data is intended to provide a common unit to allow the measurement if trends in the flow of arms to particular countries and regions over time. Therefore, the main priority is to ensure that the TIV system remains consistent over time. and that any changes introduced are backdated. [...] SIPRI TIV figures do not represent sales prices for arms transfers. They should therefore not be directly compared with gross domestic product (GDP), military expenditure, sales values or the financial value of export licences in an attempt to measure the economic burden of arms imports or the economic benefits of exports. They are best used as the raw data for calculating trends in international arms transfers over periods of time, global percentages for suppliers and recipients, and percentages for the volume of transfers to or from particular states." (SIPRI). 
of Turkish exports has been shared by a ratio of $21 \%: 79 \%$ to Outside Europe category's favour (Defence Turkey, 2014, p. 14-15).

Analysis of data presented above points to several conclusions regarding Turkey's position in the international arms market and condition of its defence industry. First, Turkey still is a net importer of defence articles. By using SIPRI's TIV calculation the general balance of imports to exports in the period of 2003-2013 amounts to a deficit of $6.925 \mathrm{bl}$. Naturally, TIV data do not reflect the actual balance of payments and contract value of goods bought and sold. However, they show the underlying pattern of military resources' transfer. This means that despite intensive efforts at increasing the level of self-sufficiency in arms production, Turkey is still heavily dependent on imports of defence articles. This trend is even more evident when product structure of imports is taken into consideration. Aircraft and ships account for more than $40 \%$ of their value. Both are among the most technology intensive and high value added products traded on the international arms market. Moreover, not many producers can offer sophisticated systems of this kind. On the other side, Turkish exports are comprised in large majority of land systems, such as armoured vehicles and artillery pieces. While these products can generate substantial revenue and require advanced technologies, they are generally less sophisticated than air and naval platforms and thus are easier to manufacture (this increases the number of suppliers on the global market) and produce less added value.

The geographical distribution of both suppliers and recipients is also telling. Turkey clearly still relies heavily on its traditional Western suppliers, with US and Germany sharing $57 \%$ of Turkish imports in 2003-2013 between them. On the other hand newly emerging players on the international defence market (like Republic of Korea and Israel) also attain strong position on the Turkish market. It must however be noted that in recent years military-industrial cooperation between Turkey and Israel soured due to general deterioration of relations between these two states. Meanwhile, Turkish exports reach primarily customers in South/South-East Asia, Middle East and Caucasus. The shift in trade in favour of partners from outside Europe recorder by the Turkish Defense and Aerospace Industry Manufacturers Association between 2011 and 2013 is especially telling (Defence Turkey, 2014, p. 15). This trend can be seen as favourable for Turkish defence industry, considering that large part of exports to Europe and USA consists of sub systems, machine molds, components and software, as well as from offset based goods and services (Defence Turkey, 2014, p. 15). At the same time customers from parts of Asia, Middle East and Caucasus are more likely to buy complete systems which generate more revenue for the exporter and does not foster the development of potential competitors.

Finally, the analysis of state's position on the global arms market should take into account international position of its main defence companies. The Top 100 defence companies ranking (which applies the criterion of defence revenue) compiled by DefenseNews magazine is among the most prestigious and popular measures of prominence in the global defence sector (DefenseNews, 2014). The 2014 edition of the ranking includes two Turkish companies: Aselsan and Turkish Aerospace Industries. Aselsan has been classified as the 67. biggest defence company in the world (it has advanced from the 74 . position in the previous edition of the ranking) with 2013 defence 
revenue of slightly over 1 bl\$ (which grew 16\% compared with 2012). The company has been established in 1975 by Land Forces Foundation (the current Turkish Armed Forces Foundation is still the biggest shareholder). Its main areas of activity are military and civilian communication systems, military electronics (including, radar, electro-optical sensor systems, command \& control, as well as electronic warfare systems, fire control systems) and air defence systems (Aselsan). Throughout the years it has become a leading supplier of communication equipment and defence electronics for the Turkish Armed Forces. In recent years it has adopted a strategy of regional expansion in search for new markets and opportunities for industrial cooperation. In 2014 it has established Aselsan Middle East, a joint venture with Jordanian King Abdullah II Design and Development Bureau (KADDB). This new entity is supposed to help Aselsan to access Jordanian and other MENA markets (Bekdil, 2014a). In 2013 Aselsan opened a plant in Kazakhstan, a joint project with Kazakhstan Engineering aimed chiefly at meeting the needs of Kazakh armed forces (Bekdil, 2014b). It is also developing close collaboration with Azeri defence industry with joint production meant to supply Azerbaijan's armed forces (News.Az, 2014).

Turkish Aerospace Industries occupies 80th position in the DefenseNews ranking (in previous edition it achieved 85 th position) with defence revenue of little less than $790 \mathrm{mS}$ (a 13,7\% growth from 2012 level) (DefenseNews, 2014). The company has been established in its current form in 2005 through a merger of Turkish Aircraft Industries Corporation (TUSAS - established by Turkish government in 1973) and TUSAS Aerospace Industries, Inc. (TAI - a joint venture with US companies created in 1984 to licence manufacture F-16 fighters). Currently it is practically completely state-owned. TAI has emerged as a primary supplier of aerospace systems for Turkish Armed Forces and a partner of choice for joint manufacturing programmes accompanying acquisition of major air systems from foreign manufacturers. Licence production of F-16 fighters ranks among the most prominent programmes realised by TAI to date. In total 308 aircraft have been assembled (262 for Turkey and 46 for Egypt). Moreover, TAI has conducted modernization programmes for Jordanian and Pakistani F-16s (TAI). Currently TAI is an important partner in the F-35 Joint Strike Fighter programme. It will produce (among other elements) central fuselage and operate one of heavy engine maintenance facilities for this type of aircraft (Mehta, 2014). TAI is also responsible for such important programmes as: GÖKTÜRK-2 (first Turkish military intelligence satellite), T-129 ATAK attack helicopter (in cooperation with Agusta Westland), Hurkus training aircraft (first aircraft completely developed in Turkey) or ANKA Medium Altitude High Endurance Unmanned Aerial Vehicle. It will also conduct conceptual work on future jet trainer and next generation fighter aircraft for the Turkish Air Force (TAI).

Both leading Turkish defence companies show certain similarities. They have been established by the state to foster technological competencies and lessen the dependence of national armed forces on foreign equipment. Despite starting with manufacturing of rather simple products, or outright license production, they have been able to develop sophisticated research and engineering capabilities of their own. Currently they are not only leading suppliers for the Turkish Armed Forces but also active players on the global arms market, not only selling complete products but also entering into industrial partnerships with foreign companies. What is most important for the future of Turkish 
defence industry, both Aselsan and TAI operate in the high-value added, advanced technology sub-sectors, which guarantee high returns and significant development potential.

\section{Assessment of future prospects for Turkish defence industry through SWOT analysis}

When trying to assess the future condition of Turkish defence industry one must take into account both internal (strengths and weaknesses) and external (opportunities and threats) factors.

Turkish defence sector can rely on two crucial strengths: a rich and diversified offer, as well as healthy investment in research \& development. Currently Turkish defence manufacturers can offer a wide range of products in majority of the most popular categories of weapon systems traded on the international market. They have built an expertise and gained respectability in armoured vehicles, small arms and defence electronics sectors. Moreover, they are constantly developing new products and expanding into new fields. Some of the most prominent examples are Altay Main Battle Tank, Tulpar Infantry Fighting Vehicle, T129 ATAK attack helicopter, ANKA Middle Altitude Long Endurance Unmanned Air Vehicle, SOM air-launched cruise missile or MILGEM corvette. Successful completion of all these programmes requires mastering of advanced skills related to project management, integration of complex systems, establishment and maintenance of supply chains, as well as post-delivery servicing and support. This in turn, allows Turkish companies to widen their offer beyond traditional fields of expertise into more complex and technologically advanced items. Moreover, they strengthen their capabilities for delivery of complete systems instead of components or single platforms. In general, Turkish defence sector is able to offer a diversity of products suited to the needs of a wide range of customers with different technological needs and financial resources at their disposal.

This expansion of product range has been fuelled, to a large extent, by high level of R\&D spending. It has already been mentioned that in 2013 Turkish defence and aerospace sector has spent ca. 1 bl\$ on R\&D/R\&T (Defence Turkey, 2014, p. 15-16). Industry expenditure are complemented by generous state funding for defence technologies' development. It comes mainly in the form of military-related R\&D expenditure of the Scientific and Technological Research Council of Turkey (TÜBITTAK). In 2012 it has devoted $328.5 \mathrm{~m}$ Turkish lira (ca. $164.25 \mathrm{mS}$ ) for these purposes. Estimates of TÜBITAAK's military-related expenditure for 2014 amounted to $390 \mathrm{~mL}$ (ca. $156 \mathrm{~m} \$$ ) (Yentürk, 2014, p. 7). If sustained, such a level of R\&D spending can allow for continued development of new and innovative products.

Despite aforementioned strengths and rapid pace of technological development Turkish defence sector exhibits several weaknesses which may pose obstacles to its further development. As already mentioned, Turkish companies proved to be relatively successful in developing weapon systems of growing technological sophistication. However, it is true that they still, by and large, lag behind leading global manufacturers in terms of innovativeness. The new air-launched cruise missile (SOM) provides an ex- 
ample. By all means it is a modern and sophisticated weapon, however it does not dramatically differ in its performance and capabilities from similar designs of American, West European, Russian or Chinese producers, developed during the last two decades (Hypki, 2014). Similarly the new Main Battle Tank-Altay, despite promising to meet all requirements of a potential modern battlefield, has been developed in cooperation with South Korean industrial partners and largely utilises "indigenised" subsystems of foreign manufacturers, proven over time in different vehicles (army-technology.com: 21st Century Asian Arms Race, 2014). Naturally, those facts do not negate the scale of Turkish industry's achievement in sharply narrowing the technological gap separating it from global leaders in arms production. However, it does show that this gap still exists. In most cases Turkish designs do not include genuinely innovative features or concepts but rather creatively follow established trends in weapon engineering. If Turkey wants to realise its ambitions to become one of the leading players on the global defence market it will have to eliminate this technological lag. Another potentially troubling issues is, the already mentioned, product structure of Turkish arms exports. It has a large share of armoured vehicles, artillery pieces and small arms, with definitely smaller representation of complex and sophisticated air and naval systems. While the first category of items is also profitable and demanded on the global market, it occupies lower levels of the value chain. Just as economies as a whole, defence sectors develop through undertaking manufacturing of higher value-added products. Currently Turkish defence industry is on its way up in the value chain, however it will take some time before its more advanced products mature and attract first export customers.

Finally, in its defence-industrial policy Turkey faces similar dilemma as most other states with substantial defence sector. It concerns the proper balance of consolidation and competition in the national defence-industrial base. In the last two decades consolidation (both horizontal and vertical) in search of economies of scale and complementarities has been a growing trend in the industry. In both United States and Western Europe smaller defence companies merged into ever larger national and multinational corporations. The logic behind this process was that large contractors will be better suited for integration of complex systems and competition on the global market. Many countries, not present in the ranks of leading global arms manufacturers but aiming to preserve and develop their defence-industrial base, have followed the trend. Such approach is also evident in Turkey, where several subsectors of the domestic market are practically dominated by single contractors. For example TAI is a partner of choice in most aerospace programmes, while Aselsan is responsible for most defence electronics deliveries for the Turkish Armed Forces. Naturally, such arrangements should be counted among factors which contributed to those companies' spectacular development. However, the global trend towards defence industry consolidation has raised worries concerning diminishing competition on national markets. In the US a de facto oligopoly of several big defence corporations has been blamed for delays and cost overruns in a range of important weapons programmes (Clark, 1999). In the Turkish context, questions can be raised whether the reliance on "suppliers of choice" in some subsectors may potentially lead to overpricing, delays and substandard quality of products and services. It must, however be noted that in some subsectors of the Turkish de- 
fence industry (especially armoured vehicles) there is fierce competition among many suppliers (Gyürösi, 2013). There are no easy and universally applicable answers to the consolidation/competition conundrum and Turkey will have to find its own way in this respect.

Three substantial opportunities which can guarantee continued rise and development of the Turkish defence industry can be identified. First, support for the domestic industry is an important element of Turkish procurement and wider defence policy. This approach has been institutionalised in the form of the Undersecretariat for Defence Industries (SSM), established under the Ministry of National Defence in 1985. Its mission is to "constitute a modern defence industry in Turkey and to achieve the modernization of the Turkish Armed Forces. In order to attain this objective, the main principle applied by SSM is to meet military requirements through domestic suppliers in the most technically and economically feasible way possible." (SSM) The SSM has overseen procurement policy's evolution from foreign acquisition before 1990, through co-production in the 1990s to domestic development in the XXIst Century (Donaldson, 2013, p. 21). This process has been greatly aided by the Defence Industry Support Fund, which in 2012 had ca. 1.2 blS at its disposal (Yentürk, 2014, p. 4). The employment of such powerful tools attests to Turkish state's determination in development of its domestic defence-industrial base.

In foreseeable future, Turkish defence sector can also count on healthy demand for its products on both domestic and export market. Turkish defence expenditure are hardly transparent. However, analysis by SIPRI concludes that when all items contributing to defence expenditure in Turkey (and not included in the official budget of the Ministry of National Defence) are being counted, this state has one of the highest military burdens among the 44 countries in Europe covered by the SIPRI Military Expenditure Database (on the level of $2.3 \%$ of GDP) (Yentürk, 2014, p. 12-13). Moreover, research has showed that the level of military expenditure in Turkey had historically been decoupled from political business cycle (Sezgin, 2010). All this suggests a strong commitment to maintenance of high defence expenditure, allowing extensive procurement of new equipment. When considering export opportunities it is worth noting that in 2013 Middle East and North Africa were responsible for $11.1 \%$ of planned global defence expenditure with Asia and Australasia recording an even higher share of 20.6\% (Military Balance, 2014, p. 23). This augurs well, considering main directions of Turkish defence exports. Finally, forthcoming big-item modernisation programmes of the Turkish armed forces offer further opportunities for defence-industrial cooperation in the form of technology transfer and co-production for Turkish companies. As already mentioned, the requirement for extensive industrial cooperation to accompany foreign acquisition of weapon systems is an important feature of official Turkish policy. Local companies' participation in such prominent programmes as T-129 attack helicopter or Joint Strike Fighter are prominent examples.

Further development of the Turkish defence industry potentially faces two major threats, tied to its primary engines of growth - domestic demand and export opportunities. The condition of Turkish economy in coming years seems to be uncertain. Slowing growth, rising inflation and considerable current account deficit contribute to a prospect for a slowdown (Reuters, 2014; EC, 2014). Although Turkey hardly faces an im- 
minent economic and fiscal crisis, some fiscal tightening in the coming years cannot be ruled out. Rapid economic growth in the last decade created uniquely favourable conditions for an ambitious military modernisation programme and the accompanying expansion of the defence-industrial base. It has already been pointed out that the level of defence expenditure in Turkey seems to be decoupled from political business cycles. Significant cuts seem not to be on the horizon yet, especially given a tumults external security environment. However, the possibility of future reductions cannot be entirely ruled out, considering the economic conditions and significant weakening of the military's political influence. When considering Turkish defence industry's export expansion strategy it must be noted that contemporary international arms market is extremely competitive. In the face of shrinking domestic markets traditional champions from US and Western Europe pursue export deals ever more energetically. At the same time, Turkey is just one of several "emerging economies" striving to break into the ranks of major arms exporters. Such states as Brazil, South Africa, Israel or South Korea (to name just a few) are determined to increase their market share. It has already been mentioned that Turkish defence industry enjoys a favourable position on the growing defence market in the MENA region. However, such important regional players as Saudi Arabia, United Arab Emirates or Jordan invest heavily in development of their own defence-industrial base (Saab, 2014). It is a general trend that states which have historically been dependant on imports of defence materiel are raising their expectations vis-a-vis suppliers concerning defence-industrial cooperation and assistance in development of indigenous defence industry. As a consequence Turkish companies will face an uphill struggle in their export expansion.

$$
* * *
$$

It is beyond doubt that Republic of Turkey perceives its defence industry as an important tool of wider defence and security policy. Important military, political and economic functions performed by this sector seem to guarantee that robust financial, legal and institutional framework of state support will be maintained. If current trends prevail, Turkey will be able to meet an ever growing share of its armed forces' equipment needs on its own. This will increase room for Ankara to conduct independent foreign and security policy and bestow it with growing prestige and recognition of major power status. All these benefits will be especially valuable in the context of challenging and complex security environment faced by Turkey in its immediate neighbourhood. At the same time it seems highly probable that Turkish companies will increase their footprint on the global arms market, increasing market share as well as participation in multinational programmes and accompanying supply chains. This can strengthen both Turkish international political standing and its economy. However, Turkey will not be able to escape challenges and dilemmas faced by many other states striving to maintain and develop their defence industry, such as: proper attitude to consolidation, fierce competition on the global market or sustainability of current fiscal conditions. Whatever the final result it seems certain that defence-industrial policy will remain closely integrated with the overall security policy of Turkey. 


\section{Bibliography}

2013 Figures of Turkish Defence Industry, "Defence Turkey", vol. 8, no 53.

Altay Main Battle Tank, Turkey, army-technology.com, http:/www.army-technology.com/projects/ altaymainbattletank/, 21.01.2015.

Aselsan, Homepage, http://www.aselsan.com.tr/en-us, 21.01.2015.

Barkey H. J. (2014), Turkey's Syria Predicament, "Survival Global Politics and Strategy", vol. 56. no 6.

Bekdil B. E., Aselsan Launches Subsidiary in Jordan, "DefenseNews", 15.12.2014, http://www.defensenews.com/story/defense/international/asia-pacific/2014/12/15/aselsan-launches-subsidiary-in-jordan/20427365/, 21.01.2015.

Bekdil B., Turkish firm Aselsan seeks global role in defense, "Hürriyet Daily News", 16.12.2014. $\mathrm{http} / /$ www.hurriyetdailynews.com/turkish-firm-aselsan-seeks-global-role-in-defense.aspx? pageID $=238 \& n I D=75656 \&$ NewsCatID $=483,21.01 .2015$.

Defence and Security Policy of the Turkish Republic (2011), in: CIDOB International Yearbook 2011. Barcelona.

Donaldson P. (2013), Defence Innovations from Turkey, "Military Technology", no 5.

Dunne J. P., Nikolaidou E., Smith R. P. (2005), Is there an Arms Race between Greece and Turkey?. "Peace Economics, Peace Science and Public Policy", vol. 11, no 2.

Erdogan: Turkish navy to protect Gaza aid, "AlJazeera", 9.09.2011, http:/wwwaljazeera.com/ news/europe/2011/09/201198225646614806.html, 21.01.2015.

Gyürösi M. (2013), IDEF 2013, cz. 1: Wozy Bojowe [IDEF 2013, part 1: Combat Vehicles], "Nowa Technika Wojskowa" [New Military Technology], no 6.

Gyürösi M. (2014), ADEX-2014, "Nowa Technika Wojskowa” [New Military Technology], no 10.

Hypki T. (2014), JASSM - MON wspiera gospodarke, niestety nie polska [JASSM - Ministry of National Defence supports the economy, unfortunately not the Polish one], "Raport - Wojsko Technika Obronność" [Report - Military Technology Defence], no 10.

International Arms Transfers Database, Stockholm Peace Research Institute, http://www.sipri.org/research/armaments/transfers, 21.01.2015.

Karaosmanoglu A. L., Kibaroglu M. (2003), Defense Reform in Turkey, in: Post-Cold War Defense Reform: Lessons Learned in Europe and the United States, New York.

Law No 3238, Undersecretariat for Defence Industries (SSM), http://www.ssm.gov.tr/home/institutional/Sayfalar/law3238.aspx, 21.01.2015.

Mehta A., Italy, Turkey Selected for F-35 European Maintenance, "DefenseNews", 11.12.2014. http://archive.defensenews.com/article/20141211/DEFREG02/312110036/Italy-Turkey-Selected-F-35-European-Maintenance, 21.01.2015.

Ozkan B. (2014), Turkey, Davutoglu and the Idea of Pan-Islamism, "Survival Global Politics and Strategy", vol. 56, no 4

Saab B. Y. (2014), The Gulf Rising Defense Industrialization in Saudi Arabia and the UAE, Atlantic Council, http://www.atlanticcouncil.org/images/publications/The_Gulf_Rising.pdf, 21.01.2015.

Sezgin \$̧. (2010), Defence Spending and Political Business Cycles in Turkey, "Ege Akademik Bakış/Ege Academic Review", vol. 10, no 2.

Sislin J. (1994), Arms as Influence: The Determinants of Successful Influence, "The Journal of Conflict Resolution", vol. 38, no 4.

Strategic Survey 2013 The Annual Review of World Affairs, International Institute for Strategic Studies, London. 
The Military Balance 2014, International Institute for Strategic Studies, London.

The Mint countries: Next economic giants?, "BBC News Magazine", 6.01.2014, http://www.bbc.com/ news/magazine-25548060, 21.01.2015.

The Modern Battle Tanks Of Asia, 21st Century Asian Arms Race, 29.07.2014, http://21stcenturyasianarmsrace.com/2014/07/29/the-modern-battle-tanks-of-asia/, 21.01.2015.

Top 100 for 2014, "DefenseNews," http://special.defensenews.com/top-100/, 21.01.2015.

Turkey cuts growth estimates, raises inflation forecast, "Reuters", 8.10.2014, http:/www.reuters.com/ article/2014/10/08/turkey-economy-idUSL6N0S31EV20141008, 21.01.2015.

Turkey demonstrates successful evacuation operations in Libya, "Today's Zaman", http:/www.todayszaman.com/national_turkey-demonstrates-successful-evacuation-operations-in-libya 236774.html 27.02.2011, 21.01.2015.

Turkey Geopolitical tensions a risk to growth, European Commission Autumn Forecast 2014. $\mathrm{http}: / /$ ec.europa.eu/economy_finance/eu/forecasts/2014_autumn/cc_turkey_en.pdf, 21.01.2015.

Turkey's biggest defense industry company may invest in Azerbaijan, "News.Az", 11.11.2014. http://www.news.az/articles/economy/93408, 21.01.2015.

Turkish Aerospace Industries Inc., Homapege, https://www.tai.com.tr/en, 21.01.2015.

Yentürk N. (2014), Measuring Turkish Military Expenditure, "SIPRI Insights on Peace and Security", no 1 .

\section{Summary}

This paper aims to analyse the military-industrial aspects of Turkish defence policy. A sophisticated and profitable defence industry is a useful tool for a state's foreign and security policy. It not only supplies the armed forces with the necessary weapons and military equipment, but can also bring political influence on the international arena through arms transfers and military-industrial cooperation. These realities are not lost on Turkish decision makers. That is why they have made the nurturing of an indigenous defence-industrial base a distinct state policy. In this paper, the defence industry's functions in the framework of Turkish defence and security policy are defined, the condition and structure of Turkish defence and aerospace sector is analysed and conclusions regarding its future prospects are presented. This provides the basis for a wider analysis of the defence-industrial aspects of Turkish defence and security policy.

Key words: defence economics, defence industry, security policy of Turkey, international arms trade

\section{Aspekty wojskowo-przemyslowe tureckiej polityki obronnej}

\section{Streszczenie}

Artykuł stanowi analizę aspektów wojskowo-przemysłowych tureckiej polityki obronnej. Zaawansowany i zyskowny przemysł obronny stanowi użyteczne narzędzie polityki zagranicznej i bezpieczeństwa państwa. Nie tylko zaopatruje siły zbrojne w potrzebne uzbrojenie i sprzęt wojskowy, ale może również być źródłem wpływów na arenie międzynarodowej za pośrednictwem transferów uzbrojenia i współpracy wojskowo-przemysłowej. Tureccy decydenci dosko- 
nale zdają sobie sprawę z tych uwarunkowań. Z tego też względu uczynili rozwój własnej bazy obronno-przemysłowej przedmiotem jasno zarysowanej polityki. W artykule zdefiniowano funkcje przemysłu obronnego w ramach tureckiej polityki bezpieczeństwa i obronnej. Poddano również analizie stan i strukturę sektora lotniczo-zbrojeniowego tego państwa oraz przedstawiono wnioski odnośnie perspektyw jego dalszego rozwoju. Stanowi to bazę dla szerszej analizy wojskowo-przemysłowych aspektów polityki bezpieczeństwa i obronnej Turcji.

Słowa kluczowe: Ekonomika obronności, przemysł obronny, polityka bezpieczeństwa Turcji, międzynarodowy handel uzbrojeniem 